\title{
Emerging Porcine adenovirus PAdV-SVN1 and other enteric viruses in samples of industrialized meat by-products
}

\section{Fernanda Gil de Souza $^{1^{*}}$ (D) Artur Fogaça Lima ${ }^{1}$ (iD) Viviane Girardi ${ }^{1}$ (i) Thalles Guillem Machado ${ }^{1}$ Victória Brandalise ${ }^{1}$ Micheli Filippi $^{1}$ (D) Andréia Henzel ${ }^{1}$ (D) Paula Rodrigues de Almeida ${ }^{1}$ (i) Caroline Rigotto ${ }^{1}$ (D) Fernando Rosado Spilki ${ }^{1}$ (D)}

${ }^{1}$ Laboratório de Microbiologia Molecular, Instituto de Ciências da Saúde, Universidade Feevale, 93352-000, Novo Hamburgo, RS, Brasil. E-mail: nandags10@hotmail.com. *Corresponding author.

ABSTRACT: Foodborne diseases are often related to consumption of contaminated food or water. Viral agents are important sources of contamination and frequently reported in food of animal origin. The goal of this study was to detect emerging enteric viruses in samples of industrialized foods of animal origin collected in establishments from southern of Brazil. In the analyzed samples, no Hepatitis E virus (HEV) genome was detected. However, 21.8\% (21/96) of the samples were positive for Rotavirus (RVA) and 61.4\% (59/96) for Adenovirus (AdV), including Human adenovirus-C (HAdV-C), Porcine adenovirus-3 (PAdV-3) and new type of porcine adenovirus PAdV-SVN1. In the present research, PAdV-SVN1 was detected in foods for the first time. The presence of these viruses may be related to poor hygiene in sites of food preparation, production or during handling.

Key words: $P A d V-S V N 1, R V$, gastroenteritis.

Detecção de adenovírus suíno PAdV-SVN1 emergente e outros vírus entéricos em amostras de subprodutos de carne industrializados

RESUMO: As doenças transmitidas por alimentos são frequentemente descritas e relacionadas ao consumo de alimentos ou água contaminados, sendo alguns agentes virais importantes fontes de contaminação e frequentemente encontrados em alimentos de origem animal. $O$ objetivo deste trabalho foi detectar patógenos entéricos emergentes em amostras de alimentos industrializados de origem animal coletados em estabelecimentos da região sul do Brasil. Nas amostras analisadas, não foi detectado o genoma do vírus da Hepatite E (HEV). No entanto, 21,8\% (21/96) das amostras foram positivas para Rotavírus (RV) e 61,4\% (59/96) para adenovírus (AdV), incluindo Adenovírus humano-C (HAdV-C), Adenovírus porcino-3 (PAdV-3) e novo tipo de suíno adenovirus PAdV-SVN1. No presente trabalho, é descrito pela primeira vez em alimentos a presença de PAdV-SVN1. A presença desses vírus pode estar relacionada à falta de higiene em locais de preparo de alimentos, manipulação de produção.

Palavras-chave: PAdV-SVN1, RV, gastroenterites.

\section{INTRODUCTION}

Cases of foodborne diseases of diverse etiologies are often related to the consumption of food improperly handled, transported or badly stored (RODRIGUES et al., 2004). Some enteric viruses such as Adenovirus (AdV), Rotavirus (RV) and Hepatitis E virus (HEV) are important causes of diseases for human beings, all transmitted by water and contaminated food (HELDT et al., 2016; SEITZ et al., 2011; SINCLAIR et al., 2009). The presence of these viral agents was demonstrated in both sites of food preparation and handling
(MAUNULA et al., 2017) as well as in food of animal origin (HELDT et al., 2016; MYKYTCZUK et al., 2017; INTHARASONGKROH et al., 2017). Since there is no specific legislation establishing acceptable detection limits for foodborne viruses, their presence already renders it unfit for consumption (RODRIGUES et al., 2004).

Among these pathogens, Human adenoviruses (HAdV) are important etiological agents associated with urinary tract infections, respiratory diseases, conjunctivitis, gastroenteritis in both adults and children, and in immunocompromised patients it has been related to systemic fatal infections (FONG 
\& LIPP, 2005). The HAdV are non-enveloped viruses, with icosahedral capsisd and a doublestranded DNA genome; belonging to the Adenoviridae family, that includes the genus Mastadenovirus which infects mammals such as humans, swine, apes, cattle, horses, canines, sheep and rodents, being transmitted by oral fecal route (FONG \& LIPP, 2005).

The PAdV infects swine and are classified as A-C corresponding to five genotypes (JONES \& MUEHLHAUSER, 2017). These viruses are potential contamination indicators in food of animal origin, since they are present in asymptomatic animals and during the slaughter process are not totally eliminated (JONES \& MUEHLHAUSER, 2017; DE MOTES et al., 2004). The circulation of PAdV described in swine populations, being reported in feces of infected animals, wastewater and sludge (VIANCELLI et al., 2012). In 2014, a new PAdV lineage called PAdVSVN1 has been isolated from swine urothelial primary cell cultures (JERMAN et al., 2014).

The HEV and RV are also recognized as emerging pathogens responsible for causing hepatitis and much of the deaths and hospitalizations by gastroenteritis, especially in children under 5 years of age (LUCHS et al., 2015). They are non-enveloped RNA viruses, transmitted by the oral fecal route and, in the case of HEV also due to consumption of products derived from pigs, game meat and direct contact with animal reservoirs (KASORNDORKBUA et al., 2005). They are resistant to high temperatures and $\mathrm{pH}$ conditions, not being totally inactivated during the preparation of the food (RODRIGUES et al., 2004).

In this way, the analysis of HEV, RV, HAdV together with the parameters used to monitor the quality and sanitary conditions of food production environments, helps to better understand their circulation and establishments of risks to human health. The goal of this study was to detect emerging enteric pathogens in samples of industrialized foods of animal origin collected in establishments from southern Brazil.

\section{MATERIALS AND METHODS}

\section{Samples}

Ninety-six ( $n=96)$ samples were collected of processed cold meat of swine origin like salami, sausage and pâté of varied brands, containing meat or liver from swine in its components and all inspected by official food safety surveillance system. The samplings were carried out monthly from different batches in 5 commercial establishments located in the municipalities of Porto Alegre and Novo
Hamburgo, Rio Grande do Sul, from July 2016 to May 2017. After collection, they were stored at $4{ }^{\circ} \mathrm{C}$ for further processing.

\section{Molecular detection}

Sample processing, DNA and RNA extractions and cDNA synthesis

Prior to the analyzes of field samples, $1 \mathrm{~g}$ of three negative samples (salami, sausage and pâté) previously tested were added to $1 \mathrm{~g}$ of the isolated HEV and $\left(10^{3}\right.$ copies/g) yielded by Dr. Marcelo Alves Pinto (FIOCRUZ/ Rio de Janeiro, Brazil) and homogenized with Minimum Essential Medium (E-MEM) pH 7. The RNA extraction was performed with TRIZOL protocol and then cDNA synthesis using $10 \mathrm{uL}$ of RNA- was performed with commercial kit High Capacity (Applied Biosystems), following the manufacturer's methodology. The DNA extraction was performed from the commercial Viral Mini Spin Plus extraction kit (Biopur ${ }^{\circledR}$, Brazil) following the manufacturer's instructions.

\section{RT-Nested PCR for detection of HEV and AdV of different species}

The detection of HEV by RT-Nested PCR was performed according to the protocol previously proposed by (HELDT et al., 2016) using primers for region ORF1 and for $\mathrm{AdV}$ according to (LI et al., 2010) for the region of DNA polymerase. The reaction had a final volume of $50 \mathrm{uL}$ containing $25 \mathrm{uL}$ of Promega GoTaq Green Master Mix, $18 \mathrm{uL}$ of water DNase/RNase free, 1 ul of each primer with 20 pmol and $5 \mathrm{uL}$ of cDNA or DNA. For amplification it was used for HEV the program with starting temperature of $95{ }^{\circ} \mathrm{C}$ to $5 \mathrm{~min}$, followed by 45 cycles of $95{ }^{\circ} \mathrm{C}$ for $30 \mathrm{~s}, 59^{\circ} \mathrm{C}$ for $1 \mathrm{~min}, 72{ }^{\circ} \mathrm{C}$ for $1 \mathrm{~min}$ and at the end of the cycles $72{ }^{\circ} \mathrm{C}$ for $7 \mathrm{~min}$. For $\mathrm{AdV}$ initial temperature of $94^{\circ} \mathrm{C}$ to $5 \mathrm{~min}$, followed by 35 cycles of $94{ }^{\circ} \mathrm{C}$ for $1 \mathrm{~min}, 50{ }^{\circ} \mathrm{C}$ for $1 \mathrm{~min}, 72{ }^{\circ} \mathrm{C}$ for $1 \mathrm{~min}$ and, at the end of the cycles $72.8{ }^{\circ} \mathrm{C}$ for $7 \mathrm{~min}$. The second PCR reaction was performed under the same conditions. After the reactions, the electrophoresis of the amplified products $(\sim 250 \mathrm{pb})$ was done and the results visualized with UV light.

\section{$R T-P C R$ for $R V$ detection}

For RV detection was performed by RTPCR, using primers according to (SPILKI et al., 2013) for VP6 region. The reaction had a final volume of $50 \mathrm{uL}$, containing $25 \mathrm{uL}$ of Promega GoTaq Green Master Mix, $18 \mathrm{uL}$ of water DNase/RNase free, $1 \mathrm{ul}$ of each primer with $20 \mathrm{pmol}$ and $5 \mathrm{uL}$ of cDNA. The program used consisted of initial temperature of $94{ }^{\circ} \mathrm{C}$ 
for $5 \mathrm{~min}$, followed by 35 cycles of $94^{\circ} \mathrm{C}$ for $1 \mathrm{~min}$, $54{ }^{\circ} \mathrm{C}$ for $1 \mathrm{~min}, 72{ }^{\circ} \mathrm{C}$ for $1 \mathrm{~min}$ and, at the end of the cycles, $72.8^{\circ} \mathrm{C}$ for $7 \mathrm{~min}$. After the reactions the electrophoresis of the amplified products was done and the results visualized with UV light.

\section{Sequencing and phylogenetic analysis}

The sequencing of the nucleotides was performed on the positive samples for AdV. The fragments were purified using the kit PureLink Quick Gel Extraction \& Purification Combo Kit (Ambion ${ }^{\mathrm{TM}}$, Life Technologies, Löhne, Germany), following the manufacturer's instructions, sequenced at the ABI Prism 3700 Genetic Analyzer and analyzed using the software BioEdit 7.0.5. Phylogenetic analysis was conducted using Neighbor-Joining (SAITOU AND NEI, 1987) and Kimura 2-parameter (KIMURA et al., 1980). The final phylogenetic tree was inferred using 500 repetitions (boostrap method) in MEGA5 phylogeny software (TAMURA et al., 2011). The phylogenetics trees were constructed based on amplified fragments, excluding the primer region. Thus, the sequences used to construct the phylogenetic trees present $\sim 230 \mathrm{bp}$.

\section{RESULTS}

The HEV genomes were not detected in all 96 samples tested . Conversely, 21.8\% (21/96) of the samples were positive for RVA, in which $12.5 \%$ (12/96) were salami samples and 9.3\% (9/96) were pâté and no RV presence in sausage samples. The AdV was the most prevalent pathogen, being reported in $61.4 \%(59 / 96)$ of the samples, in which $17.7 \%$ (17/96) were sausage samples, $20.8 \%$ (20/96) were salami samples and $22.9 \%$ (22/96) were pâté samples. Through sequencing and phylogenetic analysis of AdV (Figure 1) positive samples revealed three samples belonging to the Human adenovirus-C (HAdV-C), one sample belonging to the species Porcine adenovirus-3 (PAdV-3) and in 27 samples the emerging species PadV-SVN1 has been reported.

\section{DISCUSSION}

The viral infections are a major cause of gastroenteritis in children and adults worldwide, and mainly in developing countries account for the majority of hospitalizations due to consumption of contaminated food (RODRIGUES et al., 2004; PARASHAR et al., 2003). Foods of animal origin have been recognized as the main source of contamination by these pathogens, being evidenced in several studies (COLSON et al., 2010; BOUAMRA et al., 2014; MASUDA et al., 2005).

In the present study, no samples were positive for HEV, but other studies have demonstrated its circulation in meat and pâté products. In Brazil the presence of HEV in water samples was not detected, but in samples of swine origin there was positivity in $36 \%$ of the samples (HELDT et al., 2016), in Canada in $36 \%$ of the pâté samples (MYKYTCZUK et al., 2017), in France in $58 \%$ of processed cold meat samples (COLSON et al., 2010) and in Thailand in a lower prevalence of $0.28 \%(3 / 1090)$ in livers and $0.36 \%(2 / 559)$ in meat products, compared to $3.93 \%$ (50/1273) of swine meat samples from abattoirs (INTHARASONGKROH et al., 2017). In a study in France, was also reported the presence of infectious HEV particles in processed cold meat samples, from inoculation in cell culture and confirmation by electron microscopy (BERTO et al., 2013). Although, the presence of HEV in food was widely described, during the period studied in the present research the presence of HEV genome is not detected in food samples analyzed.

The presence of RV in food is reported in previous studies in Brazil, the genome was detected in $11.1 \%$ of the analyzed vegetable samples (WERNECK et al., 2017); in Africa was described lower prevalence, being detected only in $1.7 \%$ of the analyzed vegetable samples (VAN ZYL et al., 2006). In food of animal origin, the presence of this pathogen had not been described so far. However, in the present study it was reported in $21.8 \%(21 / 96)$ of the samples, in which $12.5 \%(12 / 96)$ and $9.3 \%$ (9/96) were salami and pâté samples, respectively. These findings demonstrated low hygiene conditions in the sites of food preparation, food production and especially during handling. This was also evidenced in a study conducted in Brazil, in which 51 employees hospitalized with gastroenteritis had consumed food previously handled by an employee diagnosed with RV infection (RODRIGUES et al., 2004). In a study by CARPENTER et al., (2013), 60\% of food handlers had symptoms of gastroenteritis during work, which favors the spread of these pathogens through food and the occurrence of outbreaks that are often not reported.

The AdV was the most frequent pathogen reported, being detected in $61.4 \%(59 / 96)$ of the samples, in which $17.7 \%$ (17/96), 20.8\% (20/96) and $22.9 \%(22 / 96)$ were samples of sausage, salami and pâté, respectively. Detection of these agents in food may be related not only to transportation, packaging and handling, but also to hygiene in production sites. In a study carried out in Finland, which evaluated the 


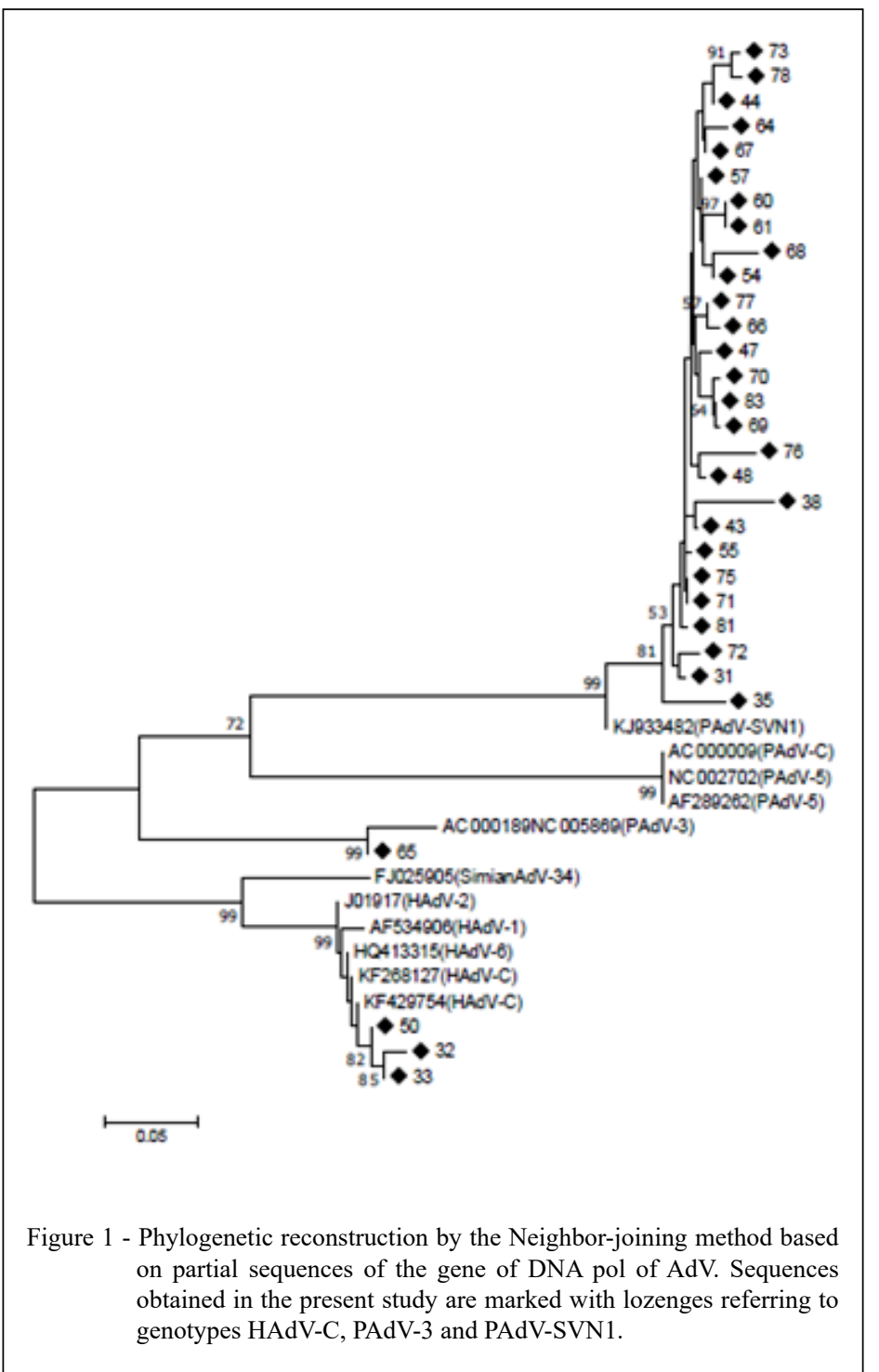

presence of enteric viruses on school, cafeteria and restaurant surfaces, AdV was detected in $26.7 \%$ of the analyzed sites (MAUNULA et al., 2017).

The PAdV is prevalent in swine populations detected in feces and urine from both symptomatic and asymptomatic animals as well as in environmental matrices (VIANCELLI et al., 2012; HUNDESA et al., 2006). In the analyzed samples, the presence of PAdV-3 and PAdV-SVN1 was evidenced, so far not detected in meat products. The PAdV-SVN1 was first described in Singapore in pig oral secretions samples (POH et al., 2017) and in the present work, its circulation evidenced in Brazil and more than this, as a frequent contaminant of pork meat. In meatpacking industry the presence of PAdV may reach $100 \%$ of pig carcasses after bleeding and the virus are not completely eliminated during the later stages of the slaughter process due to its resistance to washing and temperatures used (JONES \& MUEHLHAUSER, 2017). Thus, these pathogens demonstrate to be potential fecal contamination indicators, even though its infectivity cannot be confirmed due to the difficulty of isolation in food samples; however, this studies may help in the tracing of sources of contamination throughout the food production process.

\section{ACKNOWLEDGMENTS}

This research was grant supported by Fundação de Amparo à Pesquisa do Estado do Rio Grande do Sul (FAPERGS),

Ciência Rural, v.50, n.12, 2020. 
Conselho Nacional de Desenvolvimento Científico e Tecnológico (CNPq) and Coordenação de Aperfeiçoamento de Pessoal de Nível Superior (CAPES).

\section{DECLARATION OF CONFLICT OF INTERESTS}

The authors declare no conflict of interest. The funding sponsors had no role in the design of the study; in the collection, analyses, or interpretation of data; in the writing of the manuscript, and in the decision to publish the results.

\section{AUTHORS' CONTRIBUTIONS}

All authors contributed equally for the conception and writing of the manuscript. All authors critically revised the manuscript and approved of the final version.

\section{REFERENCES}

BERTO, A. et al. Hepatitis E virus in pork liver sausage, France. Emerging infectious diseases, v.19, n.2, p.264, 2013 Available from: <https://www.ncbi.nlm.nih.gov/pmc/articles/ PMC3563277/>. Accessed: Nov. 12, 2018. doi: 10.3201/ eid1902.121255.

BOUAMRA, Y. et al. Emergence of autochthonous infections with hepatitis E virus of genotype 4 in Europe. Intervirology, v.57, n.1, p.43-48, 2014. Available from: <https://www.ncbi.nlm.nih.gov/ pubmed/24157452?dopt=Abstract $>$. Accessed: Nov. 12, 2018. doi: $10.1159 / 000354801$

CARPENTER, L. R. et al. Food worker experiences with and beliefs about working while ill. Journal of food protection, v.76, n.12, p.2146-2154, 2013. Available from: <http://www. jfoodprotection.org/doi/abs/10.4315/0362-028X.JFP-13-128>. Accessed: Nov. 12, 2018. doi: 10.4315/0362-028X.JFP-13-128.

COLSON, P. et al. Pig liver sausage as a source of hepatitis E virus transmission to humans. The Journal of infectious diseases, v.202, n.6, p.825-834, 2010. Available from: <https://academic. oup.com/jid/article/202/6/825/935689>. Accessed: Nov. 12, 2018 doi: $10.1086 / 655898$

DE MOTES, C. M. et al. Detection of bovine and porcine adenoviruses for tracing the source of fecal contamination. Applied and environmental microbiology, v.70, n.3, p.1448-1454, 2004. Available from: <https://aem.asm.org/content/70/3/1448. short>. Accessed: Nov. 12, 2018. doi: 10.1128/AEM.70.3.14481454.2004.

FONG, T.-T.; LIPP, E. K. Enteric viruses of humans and animals in aquatic environments: health risks, detection, and potential water quality assessment tools. Microbiol. Mol. Biol. Rev., v.69, n.2, p.357-371, 2005. Available from: <https://mmbr.asm.org/ content/69/2/357.short>. Accessed: Nov. 12, 2018. doi: 10.1128/ MMBR.69.2.357-371.2005.

HELDT, F. H. et al. Hepatitis E virus in surface water, sediments, and pork products marketed in Southern Brazil. Food and environmental virology, v.8, n.3, p.200-205, 2016. Available from: <https://link.springer.com/article/10.1007/s12560016-9243-7>. Accessed: Nov. 12, 2018. doi: 10.1007/s12560016-9243-7.
HUNDESA, A. et al. Identification of human and animal adenoviruses and polyomaviruses for determination of sources of fecal contamination in the environment. Applied and environmental microbiology, v.72, n.12, p.7886-7893, 2006. Available from: <https://aem.asm.org/content/72/12/7886.short>. Accessed: Nov. 12, 2018. doi: 10.1128/AEM.01090-06.

INTHARASONGKROH, D. et al. Hepatitis E virus in pork and variety meats sold in fresh markets. Food and environmental virology, v.9, n.1, p.45-53, 2017. Available from: <https://link. springer.com/article/10.1007/s12560-016-9258-0>. Accessed: Nov. 12, 2018. doi: 10.1007/s12560-016-9258-0.

JERMAN, U. D. et al. A novel strain of porcine adenovirus detected in urinary bladder urothelial cell culture. Viruses, v.6, n.6, p.2505-2518, 2014. Available from: <https://www.mdpi. com/1999-4915/6/6/2505/html>. Accessed: Nov. 12, 2018. doi: $10.3390 / \mathrm{v} 6062505$

JONES, T. H.; MUEHLHAUSER, V. F-coliphages, porcine adenovirus and porcine teschovirus as potential indicator viruses of fecal contamination for pork carcass processing. International journal of food microbiology, v.241, p.237-243, 2017. Available from: <https://www.sciencedirect.com/science/article/pii/ S0168160516305694>. Accessed: Nov. 12, 2018. doi: 10.1016/j. ijfoodmicro.2016.10.032.

KASORNDORKBUA, C. et al. Infectious swine hepatitis E virus is present in pig manure storage facilities on United States farms, but evidence of water contamination is lacking. Applied and environmental microbiology, v.71, n.12, p.7831-7837, 2005. Available from: <https://aem.asm. org/content/71/12/7831.short $>$. Accessed: Nov. 12, 2018. doi: 10.1128/AEM.71.12.7831-7837.2005.

KIMURA, M. A simple method for estimating evolutionary rates of base substitutions through comparative studies of nucleotide sequences. Journal of molecular evolution, v.16, n.2, p.111-120, 1980. Available from: <https://link.springer.com/article/10.1007/ BF01731581>. Accessed: Nov. 12, 2018. doi: 10.1007/ BF01731581.

LI, Y. et al. Host range, prevalence, and genetic diversity of adenoviruses in bats. Journal of virology, v.84, n.8, p.3889-3897, 2010. Available from: <https://jvi.asm.org/content $/ 84 / 8 / 3889$. short>. Accessed: Nov. 12, 2018. doi: 10.1128/JVI.02497-09.

LUCHS, A. et al. Rotavirus genotypes circulating in brazil, 20072012: implications for the vaccine program. Revista do Instituto de Medicina Tropical de São Paulo, v.57, n.4, p.305-313, 2015. Available from: <http://www.scielo.br/scielo.php?pid=S003646652015000400305\&script=sci arttext $>$. Accessed: Nov. 12, 2018. doi: $10.1590 / \mathrm{S} 0036-46652015000400006$.

MASUDA, J. et al. Acute hepatitis $\mathrm{E}$ of a man who consumed wild boar meat prior to the onset of illness in Nagasaki, Japan. Hepatology Research, v.31, n.3, p.178-183, 2005. Available from: <https://www.sciencedirect.com/science/article/abs/pii/ S1386634605000094>. Accessed: Nov. 12, 2018. doi: 10.1016/j. hepres.2005.01.008.

MAUNULA, L. et al. The presence of norovirus and adenovirus on environmental surfaces in relation to the hygienic level in food service operations associated with a suspected gastroenteritis outbreak. Food and environmental virology, v.9, n.3, p.334-341, 2017. Available from: <https://link.springer.com/article/10.1007/ 
s12560-017-9291-7>. Accessed: Nov. 12, 2018. doi: 10.1007/ s12560-017-9291-7.

MYKYTCZUK, O. et al. Prevalence and molecular characterization of the hepatitis $\mathrm{E}$ virus in retail pork products marketed in Canada. Food and environmental virology, v.9, n.2, p.208-218, 2017. Available from: $<$ https://link.springer.com/article/10.1007/s12560017-9281-9>. Accessed: Nov. 12, 2018. doi: 10.1007/s12560017-9281-9.

PARASHAR, U. D. et al. Global illness and deaths caused by rotavirus disease in children. Emerging infectious diseases, v.9, n.5, p.565, 2003. Available from: <https://www.ncbi.nlm.nih. gov/pmc/articles/PMC2972763/>. Accessed: Nov. 12, 2018. doi: 10.3201/eid0905.020562.

RODRIGUES, M. M. et al. Indícios de Rotavirus na etiologia de um surto de infecção de origem alimentar. Ciência Tecnol Alim, v.24, n.1, p.88-93, 2004. Available from: <http://www. scielo.br/pdf/\%0D/cta/v24n1/20047.pdf >. Accessed: Nov. 12, 2018.

SAITOU, N. et al. The neighbor-joining method: a new method for reconstructing phylogenetic trees. Molecular biology and evolution, v.4, n.4, p.406-425, 1987. Available from: <https:// academic.oup.com/mbe/article/4/4/406/1029664>. Accessed: Nov. 12, 2018. doi: 10.1093/oxfordjournals.molbev.a040454.

SEITZ, S. R. et al. Norovirus human infectivity and persistence in water. Applied and environmental microbiology, p.AEM. 05806-11, 2011. Available from: <https://aem.asm.org/content/ early/2011/08/19/AEM.05806-11.short>. Accessed: Nov. 12, 2018. doi: 10.1128/AEM.05806-11.

SINCLAIR, R. G et al. Viruses in recreational water borne disease outbreaks: a review. Journal of Applied Microbiology, v.107, n.6, p.1769-1780, 2009. Available from: <https://onlinelibrary.wiley. com/doi/full/10.1111/j.1365-2672.2009.04367.x>. Accessed: Nov. 12, 2018. doi: 10.1111/j.1365-2672.2009.04367.x.

SPILKI, F. R. et al. Detection of human adenovirus, rotavirus and enterovirus in water samples collected on dairy farms from Tenente Portela, Northwest of Rio Grande do Sul, Brazil. Brazilian Journal of Microbiology, v.44, n.3, p.953-957, 2013. Available from: <http://www.scielo.br/scielo.php?pid=S1517$83822013000300046 \&$ script $=$ sci arttext $>$. Accessed: Nov. 12, 2018. doi: 10.1590/S1517-83822013000300046.

TAMURA, K. et al. MEGA5: molecular evolutionary genetics analysis using maximum likelihood, evolutionary distance, and maximum parsimony methods. Molecular biology and evolution, v.28, n.10, p.2731-2739, 2011. Available from: <https://academic. oup.com/mbe/article/28/10/2731/973375>. Accessed: Nov. 12, 2018. doi: $10.1093 / \mathrm{molbev} / \mathrm{msr} 121$.

VAN ZYL, W. B. et al. Molecular epidemiology of group A rotaviruses in water sources and selected raw vegetables in southern Africa. Applied and environmental microbiology, v.72, n.7, p.45544560, 2006. Available from: $<$ https://aem.asm.org/content/72/7/4554. short>. Accessed: Nov. 12, 2018. doi: 10.1128/AEM.02119-05.

VIANCELLI, A. et al. Detection of circoviruses and porcine adenoviruses in water samples collected from swine manure treatment systems. Research in veterinary science, v.93, n.1, p.538-543, 2012. Available from: $<$ https://www.sciencedirect.com/ science/article/abs/pii/S0034528811002748>. Accessed: Nov. 12, 2018. doi: 10.1016/j.rvsc.2011.07.022

WERNECK, L et al. Dissemination of gastroenteric viruses in the production of lettuce in developing countries: a public health concern. FEMS microbiology letters, v.364, n.9, 2017. Available from: <https://academic.oup.com/femsle/ article/364/9/fnx085/3746134>. Accessed: Nov. 12, 2018. doi: $10.1093 /$ femsle/fnx085. 